\title{
Edukasi pada Ibu Hamil tentang Covid-19 di Kelurahan Thehok Kota Jambi
}

\author{
Hesty \\ Program Studi DIII Keperawatan, STIKes Baiturrahim Jambi \\ Email : hestywiqi@gmail.com
}

Submitted : 29/04/2021

Accepted: 12/06/2021

Published: 28/06/2021

\begin{abstract}
Health is a need of every human being, this can only be achieved if the community, both individually and in groups, participates in increasing their ability to live a healthy life. Currently, positive cases of COVID-19 have existed in all provinces in Indonesia (34 Provinces). The COVID19 pandemic has an impact on various problems, namely the status of public health, economy, education, the socio-cultural conditions of the community including the stigma about COVID-19 which causes discrimination, security problems. The health condition of prospective mothers during early pregnancy will affect the success rate of pregnancy and the condition of the health status of the prospective baby who is still in the womb or who has already been born, so it is recommended that the prospective mother can maintain a healthy lifestyle and avoid factors that can affect the condition of the prospective mother during pregnancy. This community service activity was carried out at RT 16 Kelurahan Thehok which is located on Jalan Adityawarman, South Jambi District, Jambi City. This activity was carried out in January 2021. The service method used a survey, lecture, and discussion approach. The results achieved were health education about the implementation of the Covid-19 health protocol to pregnant women when they were outside the home, especially in crowded places and this could be understood and carried out by pregnant women when they were outside the home and in crowded places and giving masks and covid-guidebooks. 19.
\end{abstract}

Keywords: pregnant women, Covid-19

\begin{abstract}
Abstrak
Kesehatan merupakan kebutuhan setiap insan, hal ini hanya dapat dicapai bila masyarakat, baik secara individu maupun kelompok, berperan serta untuk meningkatkan kemampuan hidup sehatnya. Saat ini, kasus positif COVID-19 sudah ada di semua provinsi di Indonesia (34 Provinsi). Pandemi COVID-19 berdampak pada berbagai permasalahan yaitu status kesehatan masyarakat, ekonomi, pendidikan, kondisi sosial-budaya masyarakat termasuk adanya stigma tentang COVID19 yang menimbulkan diskriminasi, gangguan keamanan.Kondisi kesehatan calon ibu pada masa awal kehamilan akan mempengaruhi tingkat keberhasilan kehamilan serta kondisi status kesehatan calon bayi yang masih didalam rahim maupun yang sudah lahir, sehingga disarankan agar calon ibu dapat menjaga perilaku hidup sehat dan menghindari faktor-faktor yang dapat mempengaruhi kondisi calon ibu pada masa kehamilan. Kegiatan pengabdian masyarakat ini dilaksanakan di RT 16 Kelurahan Thehok yang terletak di Jalan Adityawarman Kecamatan Jambi Selatan Kota Jambi. Kegiatan ini dilaksanakan pada Bulan Januari 2021. Metode pengabdian menggunakan pendekatan survei, ceramah, dan diskusi. Hasil yang dicapai adalah penyuluhan kesehatan tentang pelaksanaan protokol kesehatan Covid-19 pada ibu hamil saat berada diluar rumah terutama ditempat keramaian dan hal ini dapat dipahami dan dilakukan oleh ibu hamil tersebut saat berada diluar rumah serta di tempat keramaian dan pemberian masker serta buku panduan covid-19.
\end{abstract}

Kata Kunci : ibu hamil, covid-19

\section{PENDAHULUAN}

Kesehatan merupakan kebutuhan setiap insan, hal ini hanya dapat dicapai bila masyarakat, baik secara individu maupun kelompok, berperan serta untuk meningkatkan kemampuan hidup sehatnya. Kemandirian masyarakat diperlukan untuk mengatasi masalah kesehatannya dan 
menjalankan upaya pemecahannya sendiri adalah kelangsungan pembangunan.yang tertuang dalam Garis-Garis Besar Haluan Negara ( GBHN ) mengamanatkan agar dapat dikembangkan suatu sistem kesehatan nasional yang semakin mendorong peningkatan peran serta masyarakat. (Notoatmodjo, 2007).

Sejak bulan Maret 2020 WHO telah menetapkan sebagai pandemi dan Indonesia menetapkan sebagai Bencana Nasional yang perlu penanganan secara komprehensif. COVID-19, sangat mudah menular dari manusia yang sakit ke manusia sehat, sehingga jumlah kasus positif setiap hari terus mengalami peningkatan. Saat ini, kasus positif COVID19 sudah ada di semua provinsi di Indonesia (34 provinsi). Pandemi COVID19 berdampak pada berbagai permasalahan yaitu status kesehatan masyarakat, ekonomi, pendidikan, kondisi sosial-budaya masyarakat termasuk adanya stigma tentang COVID-19 yang menimbulkan diskriminasi, gangguan keamanan.

Kemampuan masyarakat perlu ditingkatkan terus menerus untuk menolong dirinya sendiri dalam mengatasi masalah kesehatan. Kegiatan pembinaan yang di lakukan oleh tim kesehatan sendiri antara lain mempromosikan kesehatan dalam pelayanan, memberikan penyuluhan kesehatan kepada masyarakat mengenai berbagai pendidikan kesehatan yang dapat di berikan tim kesehatan (perawat) termasuk memberikan asuhan kepada ibu selama masa kehamilan.

Kehamilan merupakan suatu keadaan dimana seorang wanita yang didalam rahimnya terdapat embrio atau fetus. Kehamilan dimulai pada saat masa konsepsi hingga lahirnya janin, dan lamanya kehamilan dimulai dari ovulasi hingga partus yang diperkirakan sekitar 40 minggu dan tidak melebihi 43 minggu (Kuswanti, 2014). Jumlah ibu hamil di Indonesia pada tahun 2017 tercatat sekitar 5.324.562 jiwa. Sedangkan di Jawa Tengah, jumlah ibu hamil mencapai 590.984 jiwa (Kemenkes RI, 2018). Kondisi kesehatan calon ibu pada masa awal kehamilan akan mempengaruhi tingkat keberhasilan kehamilan serta kondisi status kesehatan calon bayi yang masih didalam rahim maupun yang sudah lahir, sehingga disarankan agar calon ibu dapat menjaga perilaku hidup sehat dan menghindari faktor-faktor yang dapat mempengaruhi kondisi calon ibu pada masa kehamilan (Johnson, 2016).

Rukun Tetangga (RT) 16 terletak di J1. Adityawarman Sukarejo Kelurahan Thehok, Kecamatan Jambi Selatan. Memiliki warga sebanyak 395 jiwa dengan jumlah ibu-ibu 120 masih produktif. Salah satu kegiatan social ibu-ibu di RT 16 adalah kelompok Arisan Tahlilan yang diadakan seminggu sekali setiap Hari Rabu Sore dengan cara bergantian dari satu rumah ke rumah yang lain. Dan kegiatan lain yang dilakukan ibu-ibu setiap hari Minggu pagi dari jam 6.00 sampai dengan jam 7.00 adalah Senam Aerobik.

Survey awal yang dilakukan di RT 16 Kelurahan Thehok ditemukan sebagian ibuibu hamil pada saat keluar rumah terutama belanja ke warung tidak menggunakan masker, dan pada saat ditanya kenapa tidak menggunakan masker tersebut, sebagian ibu-ibu menjawab napas agak sesak, dan ada yang menjawab tidak apa-apalah tidak pakai masker, karena hanya keluar rumah sebentar saja.Adapun data ibu-ibu yang ada di RT 16 yang sedang hamiladalah sebagai berikut:

\begin{tabular}{cc}
\multicolumn{2}{c}{$\begin{array}{c}\text { Jumlah Ibu Hamil di } \\
\text { Kelurahan Thehok }\end{array}$} \\
\hline RT 16 \\
\hline Semester & Jumlah \\
Kehamilan & \\
Trimester I & 8 \\
Trimester II & 5 \\
Trimester III & 3 \\
Total & 16 \\
\hline Sumber: $($ RT 16, 2020) &
\end{tabular}


Diperoleh dari data Ketua RT 16 Kelurahan Thehok, bahwa Ibu hamil berjumlah 16 orang, namun demikian tidak menutup kemungkinan ibu-ibu lain yang tidak hamil mengetahui juga bagaimana penanganan dan pencegahan penyebaran covid-19 sehingga tidak mudah terpapar virus tersebut.

Dari uraian diatas maka kami tertarik untuk melakukan kegiatan pengabdian masyarakat dengan judul Edukasi Pada Ibu Hamil Tentang Covid-19.

\section{TARGET DAN LUARAN}

\section{a. Target}

\begin{tabular}{|c|c|c|}
\hline No & Kegiatan & Target (\%) \\
\hline 1 & $\begin{array}{l}\text { Melaksanakan } \\
\text { kegiatan } \\
\text { Penyuluhan } \\
\text { melalui edukasi } \\
\text { pada ibu hamil } \\
\text { tentang covid-19. }\end{array}$ & $\begin{array}{l}98 \% \text { ibu-ibu hamil } \\
\text { dapat memahami } \\
\text { tentang covid-19 dan } \\
\text { apabila keluar rumah } \\
\text { harus menggunakan } \\
\text { masker dan } \\
\text { menjalankan protokol kesehatan }\end{array}$ \\
\hline 2 & $\begin{array}{l}\text { Memberikan } \\
\text { masker kesehatan }\end{array}$ & $\begin{array}{l}100 \% \text { Ibu-ibu hamil } \\
\text { mendapatkan masker } \\
\text { dan selalu } \\
\text { menggunakannya } \\
\text { disaat keluar rumah } \\
\text { terutama di } \\
\text { keramaian. }\end{array}$ \\
\hline 3 & $\begin{array}{l}\text { Memberikan foto } \\
\text { copy buku saku } \\
\text { protokol } \\
\text { tatalaksana covid- } \\
19\end{array}$ & $\begin{array}{l}100 \% \text { ibu-ibu hamil } \\
\text { mendapatkan buku } \\
\text { saku protokol } \\
\text { tatalaksana covid-19 }\end{array}$ \\
\hline
\end{tabular}

\section{b. Luaran}

Adapun Luaran dalam kegiatan ini adalah :

1. Teridentifikasi masalah Ibu hamil yang tidak menggunakan masker saat keluar rumah.

2. Terlaksananya kegiatan edukas ipada Ibu hamil tentang Covid-19

3. Terlaksananya pemberian masker kesehatan dan buku saku Protokol Tatalaksana Covid-19 pada Ibu hamil.

\section{METODE PELAKSANAAN}

Pelaksanaan kegiatan pengabdian ini telah dilaksanakan pada bulan Januari 2021 dengan sasaran ibu-ibu hamil di RT 16
Kelurahan Thehok Kota Jambi.. Adapun Metode perencanaan pengabdian kepada masyarakat di Panti Werdha telah dilakukan sesuai dengan rencana dan dapat diuraikan : Kegiatan ini bertujuan :

a. Memberikan edukasi pada ibu-ibu hamil tentang covid-19 untuk mengurangi terpapar covid-19.

b. Memberikan bantuan masker pada ibuibu hamil dan warga RT 16 Kelurahan Thehok

c. Ibu-ibu di RT 16 Kelurahan Thehok dapat memahami dan menerapkan pemakaian masker jika keluar rumah terutama tempat-tempat ramai.

Sasaran dalam kegiatan ini adalah ibu-ibu RT 16 Kelurahan Thehok. Total sasaran adalah 16 orang. Adapun kontribusi sasaran dalam pengabdian masyarakat ini adalah:

a. Ibu-ibu hamil yang mempunyai waktu luang menjadi peserta kegiatan pengabdian masyarakat.

b. Mengikuti semua kegiatan yang dilakukan

c. Semua ibu di RT 16 Kelurahan Thehok baik hamil maupun tidak hamil dan usia produktif.

Tahapan pelaksanaan kegiatan pengabdian kepada masyarakat ini adalah sebagai berikut:

a. Kegiatan Awal

1) Menyusun proposal kegiatan pengabdian kepada masyarakat.

2) Menyiapkan masker kesehatan.

3) Memfoto copy buku panduan tentang covid-19

4) Menyiapkan materi edukasi pada ibu hamil tentang covid-19

b. Pelaksanaan Kegiatan

1) Perkenalan antara tim pengabdian kepada masyarakat dengan sasaran.

2) Penjelasan kegiatan yang akan dilakukan dalam melibatkan sasaran.

3) Melaksanakan edukasi pada ibu hamil tentang Covid-19 
4) Memberikan masker dan duplikat buku saku protokol tatalaksna Covid-19

5) Penutupan

c. Monitoring dan Evaluasi

Monitoring dan evaluasi (Monev) dilakukan dengan teknik wawancara dan observasi langsung kepada sasaran. Cakupan Monev dalam kegiatan ini meliputi empat aspsek, yaitu sebagai berikut:

1) Monev Perencanaan

Pada aspek ini tim akan mengevaluasi kondisi mitra, tujuan program, permasalahan dan pemacahan masalah mitra, isi materi dan praktik kegiatan, media/ alat yang digunakan, sasaran dalam kegiatan pengabdian, waktu pelaksanaan evaluasi (berapa lama, dan kapan evaluasi dilaksanakan), sarana dan prasaran, dan dana yang digunakan.

2) Monev Pelaksanaan Kegiatan

Indikator keberhasilan pada aspek ini adalah:

a) Sebanyak $90-100 \%$ sasaran menghadiri setiap pertemuan pada kegiatan pengabdian.

b) Kemampuan tim dalam menyampaikan materi kepada sasaran.

c) Refleksi dan umpan balik dari peserta kegiatan.

\section{HASIL DAN PEMBAHASAN}

Kegiatan pengabdian masyarakat di RT 16 Kelurahan Thehok Kota Jambi telah dilaksanakan sesuai dengan rencana yang telah disusun. Kegiatan ini dibantu oleh mahasiswa Program Studi D3 Keperawatan.Kegiatan penyuluhan ini bertujuan agar Ibu-ibu di RT 16 Kelurahan Thehok memahami covid-19, penyebaran dan penularan serta pencegahan dan dapat memahami serta menerapkan pemakaian masker jika keluar rumah terutama tempat- tempat ramai untuk mengurangi terpapar covid-19.

Evaluasi dari program kegiatan pengabdian kepada masyarakat di RT 16 Kelurahan Thehok Kota Jambi dilaksanakan dimulai dari persiapan /perencanaan, pelaksanaan/proses dan evaluasi hasil.

Pada akhir kegiatan Luaran dari kegiatan pengabdian ini yaitu:

a. Publikasi artikel pada jurnal pengabdian masyarakat

b. Pemberian buku saku mengenai protokol tatalaksana covid-19

c. Tersedianya Media KIE ( poster tentang pencegahan covid-19).

d. Dilaksanakannya penyuluhan edukasi tentang covid-19 pada ibu hamil.

e. Ibu-ibu hamil di RT 16 Kelurahan Thehok Kota Jambi mampu memahami pengertian, penyebab, klasifikasi, tanda dan gejala, komplikasi, dan pencegahan/penanganan covid-19.

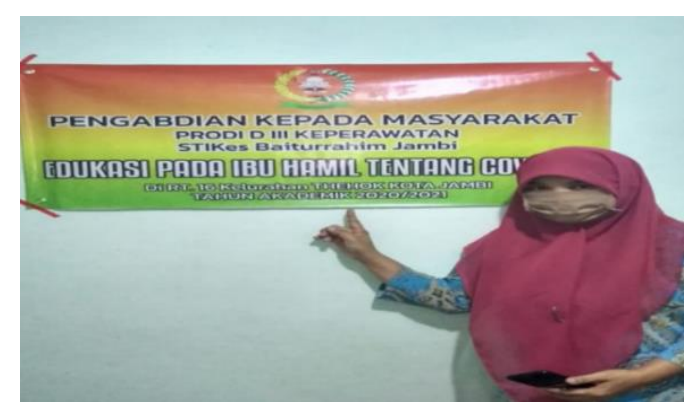

Gambar 1. Edukasi Covid-19

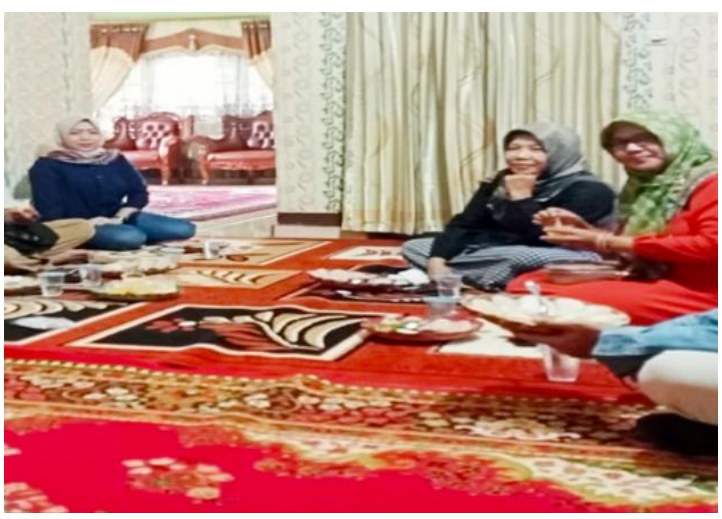

Gambar 2. Tanya Jawab

KESIMPULAN DAN SARAN

1. Kesimpulan 
$98 \%$ ibu-ibu hamil dapat memahami tentang covid-19 dan apabila keluar rumah harus menggunakan masker dan menjalankan protokol kesehatan100\% Ibu-ibu hamil mendapatkan masker dan selalu menggunakannya disaat keluar rumah terutama di keramaian. Peserta penyuluhan melaksanakan protokol kesehatan.

\section{Saran}

Diharapkan kepada ibu-ibu hamil tetap menjalankan protokol kesehatan selama pandemi covid-19 dimanapun berada terutama dalam berbagai kegiatan diluar rumah dan dikeramain jangn lupa selalu menggunakan masker yang telah dianjurkan. Selanjutnya dapat mengingatkan anggota keluarga dalam penerapan protokol kesehatan ini dengan baik sehingga tidak mudah terpapar covid19.

\section{UCAPAN TERIMAKASIH}

Terimakasih kepada Ketua STIKes Baiturrahim, Kepala Panti Sosial Tresna Werdha Kota Jambi dan staf yang telah mendukung dan memfasilitasi kegiatan pengabdian kepada masyarakat ini, sehingga kegiatan ini dapat terwujud.

\section{DAFTAR PUSTAKA}

Kementerian Kesehatan RI, 2020 Buku Saku Protokol Tatalaksana Covid 19 : Kemenkes RI

Kementerian Kesehatan RI, 2018 Pedoman Gizi Ibu Hamil dan Pengembangan Makanan Tambahan Ibu Hamil Berbasis Pangan Lokal. Indonesia: Kemenkes RI

Manuaba et all. 2009. Memahami Kesehatan Reproduksi Wanita Ed.2. Jakarta : EGC

Notoatmodjo. S, 2007Promosi Kesehatan Teori \& Aplikasi. Jakarta : Rineka Cipta

Prawirohardjo, Sarwono. 2011. Ilmu Kandungan Ed.3. Jakarta : PT Bina Pustaka Sarwono Prawirohardjo 